Article

\title{
What Matters? Non-Electoral Youth Political Participation in Austerity Britain
}

\author{
Muhammad Rakib Ehsan \\ Department of Politics and International Relations, Royal Holloway, University of London, Egham TW20 0EX, \\ Surrey, UK; r.ehsan@live.rhul.ac.uk
}

Received: 15 July 2018; Accepted: 11 October 2018; Published: 17 October 2018

\begin{abstract}
Since the 2008 global financial crisis, Britain's young people have been disproportionately affected by policies of welfare retrenchment. Youth disillusionment with austerity has been cited as a reason for the youthquake witnessed in the 2017 General Election, where the Labour Party's better-than-expected performance resulted in the loss of the ruling Conservative Party government's parliamentary majority. The degree of one-party dominance among younger voters was unprecedented, with Labour's aggressively pro-youth agenda paying dividends. However, this paper takes the attention away from voting behaviour and towards non-electoral forms of youth political participation in the UK. What are the strongest predictors of non-electoral political participation among young British people? Three possible predictors are explored: educational attainment, level of trust in politicians, and party identification. Three forms of non-electoral participation are considered: signing a petition, taking part in a boycott and sharing political messages on social media. Using a bespoke representative survey commissioned by Hope Not Hate, this paper finds that educational attainment does not have a particularly strong effect on non-electoral participation, with Labour Party identification being significantly associated with all three forms. A strong relationship is also discovered between identifying with a 'minor party' and non-electoral political participation among Britain's young people.
\end{abstract}

Keywords: young people's politics; austerity; petition; boycott; social media

\section{Introduction}

While the argument for there being a youthquake at the last General Election has been convincingly made [1-4], there are those who have disputed such findings on the basis of turnout, describing it as a mere "myth" or at best "tremor" [5]. This ongoing dispute however has led to an "over-focus" of sorts on young people's electoral participation in the UK. This means that research looking into non-electoral participation among Britain's young people in the context of austerity remains relatively underdeveloped. As well as sharp intergenerational divides in party choice, the 2017 General Election saw intragenerational differences in electoral participation among young people based on gender and education [2,3]. It is worth investigating whether such intragenerational differences are reflected in forms of non-electoral participation.

Citizen participation-non-electoral as well as electoral-is the cornerstone of liberal democratic societies [6-8]. It has been argued that citizenship participation is at the "heart of democracy" and that democracy is "unthinkable without the ability of citizens to participate freely in the government process" [9]. There has been a general consensus that there has been a "crisis of Western democracy" in recent times. This has been attributed to a number of factors: depressed trust in conventional politics [10], the transfer of policy-making to non-political institutions [11], increasingly negative media representations of politicians and formal institutions [12], and the individualisation of socio-political values $[13,14]$. This has in turn contributed to worryingly low levels of turnout [15] and declining 
party memberships [16] in recent times, with young people becoming particularly alienated from mainstream conventional politics in industrial European democracies [17,18].

However, this is not to say that young people across Europe are politically disinterested or apathetic. Indeed, they engage and interact with the democratic system in a variety of ways [18-20]. While becoming disillusioned with conventional politics in recent times, the aftermath of the 2008 global financial crisis has witnessed a resurgence in youth political protest [21]. The hallmark of young people's politics in the post-financial crisis era is the sheer diversity in political participation and engagement-ranging from signing petitions, taking part in boycotts and demonstrations, wearing political badges and sharing political content on social media platforms such as Facebook and Twitter. These diverse modes of non-electoral participation collectively represent a flexible, non-institutional approach to democratic engagement- "from Twitter to the town square" [22].

Voting patterns from last year's General Election suggest that Labour's dominance of the "youth vote" was associated with its aggressively youth-oriented policy agenda and broader opposition to government austerity [2,3]. While research on how austerity has shaped young people's vote choice is relatively well-developed, in-depth analysis of how it has conditioned non-electoral forms of political participation is currently underdeveloped. Research into young people's political participation is particularly important for a number of reasons. It provides a window into how our democracies may look in the future [23]. Young citizens transiting into adulthood are more sensitive to, and influenced by, socioeconomic change in comparison to older cohorts in society $[24,25]$. This is most relevant in the British context, as a number of studies have found that Britain's young people have disproportionately borne the brunt of government austerity and policies of welfare retrenchment [26-28].

Focusing on Britain's young people, this paper is interested in identifying the key predictors of participation in non-electoral forms of politics in the age of austerity-one which has seen higher tuition fees as major cuts have been made to higher education funding, the scrapping of the Educational Maintenance Allowance (EMA), and the abolition of housing benefits for younger people against a backdrop of inflated house prices and exorbitant rates in the private rented sector. The three most popular forms of non-electoral political participation among Britain's young people (shown later in Table 1) will be included in this paper's analysis: signing a petition, boycotting (or buying) a product for political, ethical or environmental reasons, and sharing a political message on social media. Three possible predictors are explored: educational attainment, trust in politicians and party identification.

\section{Inter-Relational Predictors: Educational Attainment, Political Trust and Party Identification}

The relationship between educational attainment and young people's participation in last year's General Election has been extensively discussed. Sloam and Ehsan [2] found that lower levels of political participation continued to be demonstrated by less-educated young people in comparison to their more highly educated counterparts, for last year's General Election. Relatively high levels of participation have been found among full-time British students-particularly those studying at university [3]. Despite the recent upturn in youth turnout and party activism in the UK, it appears that intra-generational inequalities continue to persist, with "lower-resourced" young people showing lower levels of political participation.

Previous studies have shown that educational and financial resources are highly significant in shaping and determining political participation in general populations [9,29-31]. However, it is very important to treat educational attainment and household income as individual predictors of political participation. Indeed, existing studies suggest that educational attainment has an independent, stronger relationship with political participation [32,33]. This of course gives rise to the question of why there would be a positive relationship between educational attainment and youth non-electoral political participation.

The prominence of often younger, more highly educated "critical citizens" [34] who are supportive of liberal democratic values but highly critical of the democratic system of governance, has contributed towards growing cynicism of conventional politics in recent times. This has involved 
increasing disillusionment with the performance and motives of government, political parties and politicians in general [10]. As well as the generally downward trajectory in party membership numbers [16], party attachment and political trust have steadily weakened in established industrial democracies [35]. This has been accompanied by the increasing importance of "cause-oriented politics" and "issue-specific" forms of youth political participation [36]. As well as the inability of democratic institutions and political collectives to accommodate growing diversity of opinion and individualisation of values, industrial societies, such as the UK, are also taking on an increasingly "educated" complexion, with younger people being more highly educated than previous generations [37].

Mayne and Hakhverdian [38] offer insight into the relationship between educational and political trust, with their work being based on the proposition that "citizens grant or withhold political trust based on their evaluations of the performance of political actors and institutions". Linked with the concept of the "critical citizen", Hakhverdian and Mayne [39] identify what they label as the "accuracy-inducing" and "norm-inducing" functions of education. The accuracy-inducing function enables citizens to obtain, digest and make sense of information when evaluating the performance of conventional political actors such as the government and political parties. The norm-inducing function of education makes citizens more likely to be normatively troubled by instances of institutional dysfunction and misconduct.

From this perspective, higher educational attainment would be associated with political distrust, as "critical citizens" are more likely to scrutinise the performance of political actors and are more sensitive to dysfunctional outcomes related to the broader political system. This leads to the direct relationship between political distrust and participation in non-electoral politics. Alienation from conventional politics and a lack of trust in traditional political institutions have been identified as potential contributory factors in the rise and proliferation of youth protest across Europe in times of austerity and welfare retrenchment [22]. Therefore, it is entirely plausible to expect that young people who are distrustful of conventional politics and politicians in general, will be more likely to express their concerns and grievances through non-electoral forms of political participation. Indeed, Kaase [40] found that lower political trust was associated with a higher probability of engaging in direct action in the European context.

Another possibility is that distrust of a particular political party, as opposed to disillusionment with the broader political system, can stimulate non-electoral political participation as an expression of anti-government protest. As previously discussed, government austerity in European democracies, such as the UK, has disproportionately affected younger sections of the population-which has been cited as a contributing factor of the wave of youth protests and demonstrations in Britain and much of Europe in recent times [41-43]. Therefore, there is the possibility that it is not so much anti-establishment sentiment and cynicism over conventional politics which is driving non-electoral forms of youth political participation (and protest) in recent times, but rather identification with parties which represent "anti-austerity" alternatives to fiscally conservative governing parties.

As already discussed, the Labour Party enjoyed unprecedented levels of youth support in last year's General Election, with much of this being attributed to its fervently anti-austerity manifesto which specifically targeted Britain's younger people [2,3]. There are two inter-related reasons why there could be a relationship between Labour Party identification and non-electoral participation among Britain's young people. With there being an association between austerity policies and youth protest in recent times, it would be expected that younger people who identify with "anti-austerity" parties such as Labour would be more likely to participate in non-electoral politics as a means to express their opposition to austerity policies. Secondly, Jeremy Corbyn has sought to transform the Labour Party into a "social movement" which champions "bottom-up" grassroots activism. Indeed, Labour-affiliated grassroots organisation Momentum has been directly involved in organising youth-led protests, rallies, and demonstrations, as well as actively distributing political content through social media and encouraging young members and supporters to "share" and disseminate such material [42]. 
The relevant literature reviewed regarding non-electoral youth political participation helps to develop three inter-related hypotheses which are to be tested in this paper:

Hypothesis 1. Young people who are more highly educated are more likely to participate in non-electoral forms of politics.

Hypothesis 2. Young people who are less trusting of politicians are more likely to participate in non-electoral forms of politics.

Hypothesis 3. Young people who identify with the Labour Party are more likely to participate in non-electoral forms of politics.

\section{Materials and Methods}

The three hypotheses will be tested through analysis of a representative survey of 135118 to 30-year olds conducted shortly before the referendum on EU membership on 23 June 2016 (6-13 May). The survey was commissioned by UK-based advocacy group Hope Not Hate, with YouGov carrying out the data collection. The relatively large sample provided an opportunity to investigate what drives non-electoral political participation among young British people. What are the key socio-demographic characteristics of young British people who tend to participate in non-electoral politics? Are younger people who are more distrustful of politicians more likely to participate in non-electoral politics? And what role does party identification play in young people's non-electoral political participation?

\subsection{Measurement of Key Variables}

To provide a fine-grained analysis of the in-group characteristics of 18 to 30-year olds, we examine the relative importance of educational attainment, political trust and party identification in non-electoral political participation among young British people.

This section divides the variables of interest into four sets. The first set includes the dependent non-electoral political participation variables, with the following three sets being independent variables categorised as socio-demographic characteristics, political trust and party identification.

\subsection{Dependent Variables: Non-Electoral Forms of Political Participation}

In this paper, three forms of non-electoral political participation are considered: signing a petition, sharing a political message on social media, and taking part in a boycott.

Respondents were asked: "During the past year (i.e., since May 2015), which, if any, of the following have you done?" The options offered to respondents were:

- Signed a petition;

- Shared a political/environmental message on social media;

- Bought or boycotted a product for ethical, political or environmental reasons;

- Worn or displayed a campaign badge or sticker; and

- Gone on a demonstration or attended a rally.

Table 1 shows that the first three forms of non-electoral political participation were the three most commonly reported by respondents-justifying their inclusion in this paper's analysis. The three forms of non-electoral political participation examined in the paper are treated as binary dependent variables in three separate logistic regression models (being coded on the simple No $=0$, Yes $=1$ basis). 
Table 1. Reported levels of youth participation for forms of non-electoral politics.

\begin{tabular}{cc}
\hline Mode of Non-Electoral Participation & \% of $\mathbf{1 8 - 3 0 - Y e a r ~ O l d s ~}$ \\
\hline Signing a petition & $50.2 \%$ \\
Sharing a political post on social media & $26.3 \%$ \\
Taking part in a boycott & $18.8 \%$ \\
Wearing a political badge/sticker & $9.3 \%$ \\
Participating in a demonstration & $6.4 \%$ \\
\hline Notes: Source: HopeNotHate Survey (YouGov). $n=1351$.
\end{tabular}

\subsection{Socio-Demographic Characteristics}

There are five conventional socio-demographic variables considered in the upcoming analysis: education, gender, ethnicity, social grade, and work status. In the multivariate analysis, education, which occupies an important position in this paper, is measured through a variable sectioned into three levels of educational attainment: low $=1$, medium $=2$, and high $=3$.

Gender is coded as male $=0$, female $=1$. Ethnicity is coded as white $=1$, non-white $=2$, and respondents who preferred not to say $=3$. Young white people are set as the reference category for the logistic regression analysis. Social grade is coded as $\mathrm{ABC} 1=1, \mathrm{C} 2 \mathrm{DE}=2$, with the lower $\mathrm{C} 2 \mathrm{DE}$ social grade set as the reference category in the multivariate analysis. The work status variable is recoded into 4 categories: Full-time work $=1$, Part-time work $=2$, Full-time student $=3$, and other $/$ not working $=4$.

\subsection{Political Trust}

Political trust is measured using one variable. For this variable, the relevant survey question asked to respondents was: "Generally speaking, how much do you trust a politician?" There were five response categories offered to respondents: "a great deal", "a fair amount", "not very much", "not at all", and "don't know". For the analysis, young people who responded "a great deal" are set as the reference category.

\subsection{Party Identification}

For party identification, respondents were asked: "Generally speaking, do you think of yourself as Labour, Conservative, Liberal Democrat or what?" The party identification variable is coded as Conservative $=1$, Labour $=2$, Liberal Democrat $=3$, UK Independence Party $=4$, Other Party $=5$, and None $=6$. Young people who reported identifying with the Conservative Party are set as the reference category for the logistic regression analysis.

\section{Analysis}

This section of this paper tests the three main hypotheses through multivariate analysis. In the form of binary logistic regression, these models include all variables of interest, allowing us to develop a better understanding of what drives participation in non-electoral forms of politics among young British people in the context of austerity. The three binary dependent variables are coded as $\mathrm{No}=0$ and Yes $=1$.

Table 2 presents on overview of multivariate analysis which looks into the three forms of non-electoral political participation among young people. Three models are included in the table, with Model 1 predicting for signing a petition, Model 2 predicting for sharing a political or environmental message on social media, and Model 3 predicting for boycotting (or buying) a product for political, ethical or environmental reasons. 
Table 2. Three-model table for non-electoral youth political participation (binary logistic regression).

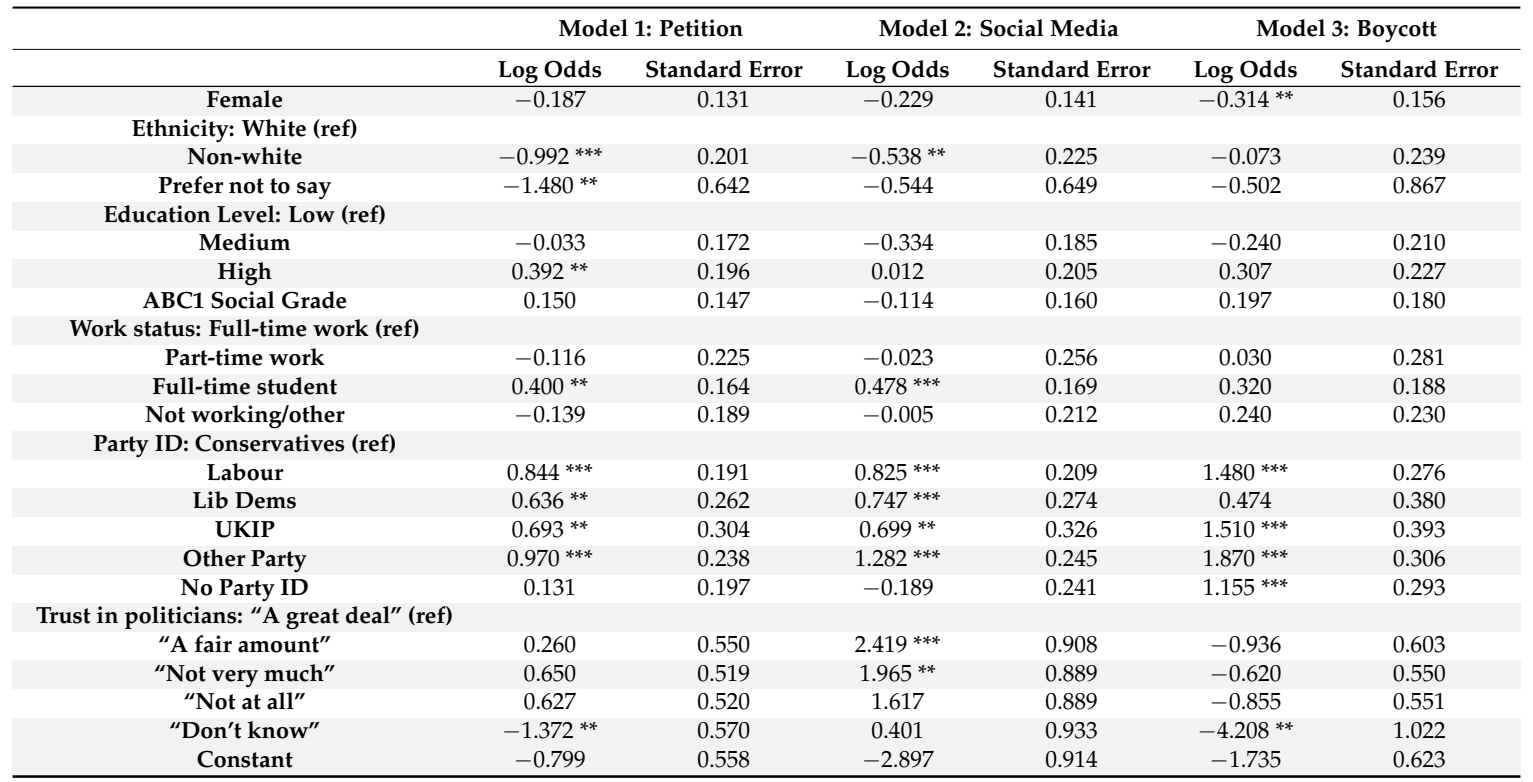

Model 1 Notes: Source: HopeNotHate Survey (YouGov). $n=1194$. Chi-Square: 192.130. Degrees of Freedom: 18. -2LL: 1422.779. Nagelkerke R-Square: 0.202. $p<0.01={ }^{* * *}, p<0.05={ }^{* *}, p<0.1={ }^{*}$. Model 2 Notes: Source: HopeNotHate Survey (YouGov). $n=1194$. Chi-Square: 133.333. Degrees of Freedom: 18. -2LL: 1272.198. Nagelkerke R-Square: 0.152. $p<0.01={ }^{* * *}, p<0.05={ }^{* *}, p<0.1=*$. Model 3 Notes: Source: HopeNotHate Survey (YouGov). $n=1$ 194. Chi-Square: 131.436. Degrees of Freedom: 18. -2LL: 1058.035. Nagelkerke R-Square: 0.167. $p<0.01={ }^{* * *}$, $p<0.05=* *, p<0.1=^{*}$.

Significant education effects are only found in Model 1, where more highly educated young people are more likely to report signing a petition than lowly-educated young people $(b=0.392)$. With no significant education effects being found in both Models 2 and 3, Hypothesis 1 is only partially satisfied.

No significant effects are found in Models 1 and 3 regarding political trust. In Model 2, young people who do not have very much trust in politicians are more likely to share a political or environmental message on social media, than young people who have a great deal of trust in politicians $(b=1.965)$. With no significant differences being found across the three models between young people who have a great deal of trust in politicians, and young people who do not trust politicians at all, there is no convincing evidence supporting the hypothesised relationship between political distrust and participation in non-electoral forms of politics. Therefore, Hypothesis 2 can be rejected.

The strongest significant effects in the analysis involve party identification. Across all three modes of non-electoral participation, young Labour identifiers are more likely to report signing a petition $(b=0.844)$, sharing a political or environmental message on social media $(b=0.825)$ and boycotting (or purchasing) a product for political, ethical or environmental reasons $(b=1.480)$, than young Conservative Party identifiers. All of these findings are significant at the $1 \%$ confidence level. This provides considerable support for Hypothesis 3.

However, the young people who are the most likely to participate in non-electoral politics across the three models are those who identify with "other parties" $(b=0.970 ; b=1.282 ; b=1.870)$. Again, all of these findings are significant at the $1 \%$ confidence level. Young people who identify with UKIP are more likely to report signing a petition $(b=0.693)$, sharing a political or environmental message on social media $(b=0.699)$ and boycotting (or buying) a product for political, ethical, or environmental reasons $(b=1.510)$, than their Conservative-identifying counterparts.

There are other noticeable trends based on the socio-demographic characteristics. Young people in full-time education are more likely to report signing a petition $(b=0.400)$ and sharing a political or environmental message on social media $(b=0.478)$, than young people who are in full-time work. In regards to ethnicity, non-white young people are less likely to report signing a petition 
$(b=-0.992)$ and sharing a political or environmental message on social media $(b=-0.538)$ than young white people.

\section{Discussion}

This paper examines non-electoral political participation among young British people in the context of austerity, finding that party identification is strongly associated with non-electoral politics in comparison to other possible predictors, such as educational attainment and political distrust.

Perhaps unsurprisingly, identifying with opposition parties is strongly related with participation in non-electoral politics among young British people. There is a possible explanation for the relatively strong relationship between Labour (and "Other party") identifiers and non-electoral forms of political participation. During his time as Labour leader, Jeremy Corbyn has sought to transform the party as a broad, anti-austerity, grassroots social movement. This means that young people who identify with Labour are being actively encouraged by the party leadership, along with affiliate bodies such as Momentum, to participate in repertoires of non-electoral politics as a means to express opposition to Conservative-led austerity.

This explanation can apply to "Other Party" identifiers if most identify with the Green Party, which traditionally champions "participatory democracy" and possesses a more horizontal, member-oriented organisational structure. With the fieldwork for the survey taking place shortly before the June 2016 referendum on EU membership, the relatively strong relationship between UKIP identification and non-electoral youth political participation is likely to be driven by effective grassroots movements within the electorally successful Leave campaign. The findings also suggest that young people who identify with minor parties which tend to be discriminated against by the workings of the majoritarian Westminster first-past-the-post electoral system may be more inclined to use non-electoral channels of political participation in order to express their views and influence the democratic system.

While previous studies have found that higher education is associated with greater cynicism of conventional politics and non-electoral modes of participation, this paper finds that this relationship is weak at best among young British people. Rather, the education-related factor which appears to drive non-electoral youth participation is whether one is in full-time education. This is perhaps unsurprising, as non-electoral forms of political expression such as signing petitions and building support for particular causes through social media are dominant features of student politics across the UK. The relationship between being in full-time education and participating in non-electoral politics builds on the findings from last year's General Election, which found that youthquake could be characterised as a "student-led revolt" driven by opposition to tuition fee increases and growing student debt [44]. Interestingly, while concerns arose over the relative under-participation of socio-economically deprived young people in last year's General Election, no social class differences were found by this paper when it comes to non-electoral youth political participation.

In regards to the direction of future research, this paper has come across an interesting point of difference in non-electoral youth political participation-ethnicity. Examining levels of turnout within the younger section of the British electorate, Sloam and Ehsan [2] concluded that the "lower-than-average participation of young BMEs is a cause for concern". The socio-political incorporation of the UK's non-white young people includes how involved they are in non-electoral forms of political participation as well as conventional politics. Future research could focus on identifying the driving factors behind the differences in both electoral and non-electoral participation between young white people and their non-white peers in the modern British context.

Funding: This research received no external funding. Rakib Ehsan received a doctoral scholarship from the Economic and Social Research Council (ESRC) for his PhD.

Conflicts of Interest: The author declares no conflicts of interest. 


\section{References}

1. Kellner, P. The British Election claims there was no "youthquake" last June. It's wrong. Prospect, 30 January 2018. Available online: https:/ / www.prospectmagazine.co.uk/blogs/peter-kellner/the-britishelection-study-claims-there-was-no-youthquake-last-june-its-wrong (accessed on 5 February 2018).

2. Sloam, J.; Ehsan, R. Youth Quake: Young People and the 2017 General Election; Intergenerational Foundation: London, UK, 2017.

3. Sloam, J.; Ehsan, R.; Henn, M. Youthquake: How and Why Young People Reshaped the Political Landscape. Political Insight 2018, 9, 4-8. [CrossRef]

4. Stewart, M.; Clarke, H.; Goodwin, M.; Whiteley, P. Yes, there was a "youthquake" in the 2017 snap election-And it mattered. New Statesman, 5 February 2018. Available online: https: / www.newstatesman. com/politics/staggers/2018/02/yes-there-was-youthquake-2017-snap-election-and-it-mattered (accessed on 7 February 2018).

5. Prosser, C.; Fieldhouse, E.; Green, J.; Mellon, J.; Evans, G. The Myth of the 2017 Youthquake Election. British Election Study. 29 January 2018. Available online: http:/ / www.britishelectionstudy.com/bes-impact/themyth-of-the-2017-youthquake-election/\#.W0dZbNJKjIU (accessed on 30 January 2018).

6. Almond, G.; Verba, S. The Civic Culture: Political Attitudes in Five Nations; Princeton University Press: Princeton, NJ, USA, 1963.

7. Bellamy, R. Evaluating Union Citizenship: Belonging: Rights and Participation within the EU. Citizsh. Stud. 2008, 12, 597-611. [CrossRef]

8. Pateman, C. Participation and Democratic Theory; Cambridge University Press: Cambridge, UK, 1970.

9. Verba, S.; Schlozman, K.; Brady, H. Voice and Equality: Civic Voluntarism in American Politics; Harvard University Press: Cambridge, MA, USA, 1995.

10. Dalton, R. Democratic Challenges, Democratic Choices: The Erosion of Political Support in Advanced Industrial Democracies; Oxford University Press: Oxford, UK, 2004.

11. Hay, C. Why We Hate Politics; Polity: Cambridge, UK, 2007.

12. Stoker, G. Why Politics Matters: Making Democracy Work; Palgrave MacMillan: Basingstoke, UK, 2006.

13. Beck, U. Risk Society: Towards a New Modernity; SAGE: London, UK, 1992.

14. Bennett, L. The UnCivic Culture: Communication, Identity, and the Rise of Lifestyle Politics. PS Political Sci. Politics 1998, 31, 41-61. [CrossRef]

15. Fieldhouse, E.; Tranmer, M.; Russell, A. Something about Young People or Something about Elections? Electoral Participation of Young People in Europe: Evidence with a Multilevel Analysis of the European Social Survey. Eur. J. Political Res. 2007, 46, 797-822. [CrossRef]

16. Van Biezen, I.; Mair, P.; Poguntke, T. Going, going ... gone? The Decline of Party Membership in Contemporary Europe'. Eur. J. Political Res. 2012, 51, 24-56. [CrossRef]

17. Norris, P. Young People and Political Activism: From the Politics of Loyalties to the Politics of Choice? Report for the Council of Europe Symposium: Young People and Democratic Institutions: From Disillusionment to Participation, Strasbourg, France, 27-28 November 2003. Available online: http://www.hks.harvard. edu/fs/pnorris/Acrobat/COE\%20Young\%20People\%20and\%20Political\%20Activism.pdf (accessed on 18 April 2018).

18. Spannring, R.; Ogris, G.; Gaiser, W. (Eds.) Youth and Political Participation in Europe: Results of the Comparative Study of Euyoupart; Barbara Budrich: Leverkusen, Germany, 2008.

19. Dalton, R. The Good Citizen: How a Younger Generation is Reshaping American Politics; CQ Press: Washington, DC, USA, 2009.

20. Norris, P. Democratic Phoenix: Reinventing Political Activism; Cambridge University Press: Cambridge, UK, 2002.

21. Sloam, J. Voice and Equality: Young People's Politics in the European Union. West Eur. Politics 2013, 36, 836-858. [CrossRef]

22. Sloam, J. Young people are less likely to vote than older citizens, but they are also more diverse in how they choose to participate in politics. London School of Economics European Politics and Policy, 19 July 2013. Available online: http://blogs.lse.ac.uk/europpblog/2013/07/19/young-people-are-less-likely-tovote-than-older-citizens-but-they-are-also-more-diverse-in-how-they-choose-to-participate-in-politics / (accessed on 12 May 2018). 
23. Hooghe, M. Political socialization and the future of politics. Acta Politica 2004, 39, 331-341. [CrossRef]

24. Flanagan, C. Young people's civic engagement and political development. In Handbook of Youth and Young Adulthood; Furlong, A., Ed.; Routledge: Abingdon, UK, 2009.

25. Franklin, M. Voter Turnout and the Dynamics of Electoral Competition since 1945; Cambridge University Press: Cambridge, UK, 2004.

26. Kingman, D. Austerity Has Hit Younger Generation Harder, Study Finds; Intergenerational Foundation: London, UK, 2015; Available online: http://www.if.org.uk/2015/02/06/austerity-has-hit-younger-generationharder-study-finds / (accessed on 11 September 2017).

27. OECD. Society at a Glance 2016: OECD Social Indicators. 2016. Available online: https:/ / www.slideshare. net/linoagudelo/society-at-a-glance-2016-oecd-social-indicators (accessed on 30 April 2018).

28. Sloam, J. Diversity ad voice: The political participation of young people in the European Union. Br. J. Politics Int. Relat. 2016, 18, 521-537. [CrossRef]

29. Li, Y.; Marsh, D. New Forms of Political Participation: Searching for Expert Citizens and Everyday Makers. Br. J. Political Sci. 2008, 38, 247-272. [CrossRef]

30. Teorell, J.; Sum, P.; Tobiasen, M. Political Participation and Political Equality: An Assessment of Large-Scale Democracy. In Citizenship and Involvement in European Democracies: A Comparative Analysis; van Deth, J., Ramón Montero, J., Westholm, A., Eds.; Routledge: London, UK, 2007.

31. Torney-Purta, J.; Lehmann, R.; Oswald, H.; Schulz, W. Citizenship and Education in Twenty-Eight Countries: Civic Knowledge and Engagement at Age Fourteen; IEA: Amsterdam, The Netherlands, 2001.

32. Bovens, M.; Wille, A. The Education Gap in Participation and its Political Consequences. Acta Politica 2008, 45, 393-422. [CrossRef]

33. Nie, N.; Junn, J.; Stehlik-Barry, K. Education and Democratic Citizenship in America; University of Chicago Press: Chicago, IL, USA, 1996.

34. Norris, P. (Ed.) Critical Citizens: Global Support for Democratic Government; Oxford University Press: Oxford, UK, 1999.

35. Dalton, R.; Wattenberg, M. (Eds.) Parties without Partisans: Political Change in Advanced Industrial Democracies; Oxford University Press: Oxford, UK, 2000.

36. Norris, P. Digital Divide: Civic Engagement; Information Poverty and the Internet Worldwide; Cambridge University Press: Cambridge, UK, 2001.

37. OECD. Education Indicators in Focus: Are Young People Attaining Higher Levels of Education Than Their Parents? 2015. Available online: https://www.oecd-ilibrary.org/docserver/5js7lx8zx90r-en.pdf?expires= $1531566294 \& \mathrm{id}=\mathrm{id} \&$ accname $=$ guest $\&$ checksum $=97$ A0A5C11F79A952F435C6B828D33D5D $($ accessed on 30 April 2018).

38. Mayne, Q.; Hakhverdian, A. Education, Socialization, and Political Trust. In Handbook on Political Trust; Zmerli, S., van der Meer, T., Eds.; Edward Elgar Publishing: Cheltenham, UK, 2016.

39. Hakhverdian, A.; Mayne, Q. Institutional Trust, Education, and Corruption: A Micro-Macro Interactive Approach. J. Politics 2012, 74, 739-750. [CrossRef]

40. Kaase, M. Interpersonal trust, political trust and non-institutionalized political participation in Western Europe. West Eur. Politics 2007, 22, 1-21. [CrossRef]

41. Lima, M.; Artiles, A. Youth Voice(s) in EU countries and social movements in southern Europe. Transf. Eur. Rev. Labour Res. 2013, 19, 345-364. [CrossRef]

42. Pickard, S.; Bessant, J. (Eds.) Young People Re-Generating Politics in Times of Crises; Palgrave MacMillan: Basingstoke, UK, 2017.

43. Zamponi, L.; Fernández Gonzalez, J. Dissenting youth: How student and youth struggles helped shape anti-austerity mobilisations in Southern Europe. Soc. Mov. Stud. 2017, 16, 64-81. [CrossRef]

44. Ehsan, R.; Sloam, J.; Henn, M. Youthquake Was Real-Here's How We Know It Was More Than a Myth; The Conversation: London, UK, 2018; Available online: http:/ / theconversation.com/youthquake-was-realheres-how-we-know-it-was-more-than-a-myth-90970 (accessed on 31 January 2018).

(C) 2018 by the author. Licensee MDPI, Basel, Switzerland. This article is an open access article distributed under the terms and conditions of the Creative Commons Attribution (CC BY) license (http://creativecommons.org/licenses/by/4.0/). 